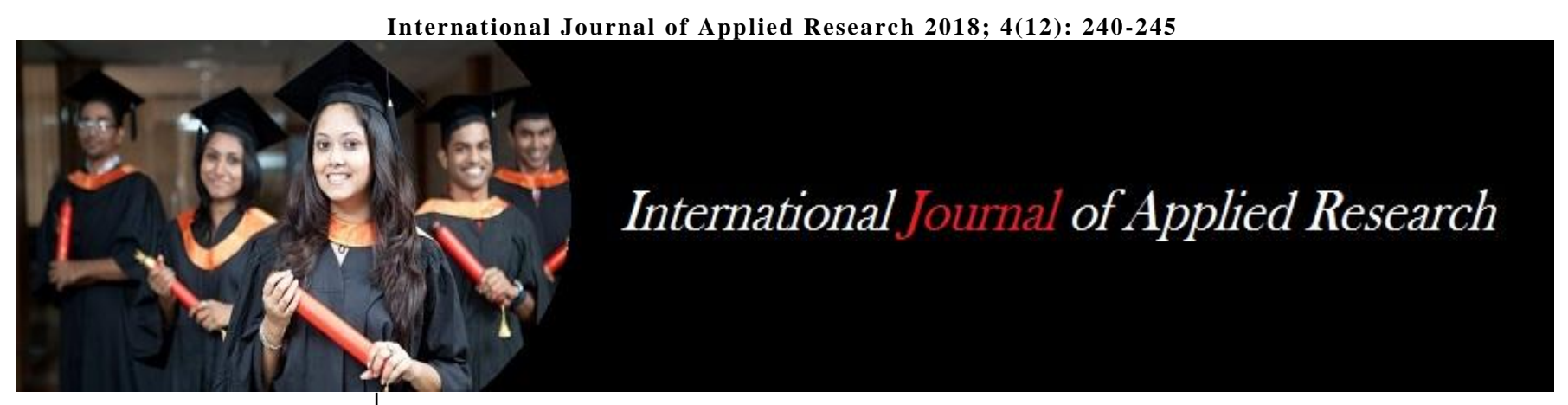

ISSN Print: 2394-7500

ISSN Online: 2394-5869

Impact Factor: 5.2

IJAR 2018; 4(12): 240-245

www.allresearchjournal.com

Received: 03-10-2018

Accepted: 08-11-2018

Philner P Salindo

Social Science Department,

College of Arts and Sciences,

Negros Oriental State

University, Guihulngan

Campus, Republic of the

Philippines

Joel T Ubat

Social Science Department,

College of Arts and Sciences,

Negros Oriental State

University, Guihulngan

Campus, Republic of the

Philippines
Correspondence

Philner P Salindo

Social Science Department,

College of Arts and Sciences,

Negros Oriental State

University, Guihulngan

Campus, Republic of the

Philippines

\section{A correlational analysis on the condition of lodging houses and students academic performance}

\author{
Philner P Salindo and Joel T Ubat
}

DOI: https://doi.org/10.22271/allresearch.2018.v4.i12d.04

\begin{abstract}
A dwelling is one of the essence of living and ensuring safety and security that translates into the holistic development of a person's well being. In this study, the lodging houses around NORSUGuihulngan City campus was evaluated and correlated to the academic performance of NORSU students who are residing in these lodging houses. Thus, the purpose of this study is to find out whether the conditions of the lodging houses affect the academic performance of students or not. Results showed that there is a significant relationship between the condition of lodging houses and the academic performance of NORSU students.
\end{abstract}

Keywords: Lodging houses, students academic performance

\section{Introduction}

Students from the provinces stay in lodging houses which are considered temporary dwellings. Their living conditions in these dwellings may result to beneficial and prejudicial contributions to their holistic well-being.

In international setting, specifically in Zululand, South Africa, the same situations are a concern of both government and academic institution. Black african students lodge in private homes and have manifested behaviors which are not encouraging in school activities. Khumalo, Blasius Dumisani (1995) conducted a research to investigate the relationship between academic performance and their private lodging homes.

Based on students' observations and testimonials these temporary dwellings fail to consider the provisions of basic and other facilities that will meet the various needs of the occupants. It is then an immediate concern of both City legislators and school administrators to know the nature of lodging houses in operation for them to formulate effective interventions to anticipate problems that may possibly occur and provide precautionary and proactive measures. Legislative interventions may also address lodging houses living-related concerns. In Guihulngan City, there has been an evident dearth of an ordinance related to this matter. Thus, it is timely for the City to build such.

Our collaborative study aims to establish the current conditions of college students living in lodging houses. Specifically, its findings hope to formulate programs or may serve as bases to create a specific set of guidelines on lodging house operation and regulations in the City. In Philippine Senate, a bill introduced by Senator Manny Villar (2012) ${ }^{[6]}$ in the Fifteenth Congress of the Philippine Republic entitled: An Act Establishing A Comprehensive And Integrated National Policy And Program Guidelines For The Operation And Maintenance Of Dormitories And Boarding-Houses, Providing Penalties Therefor, And For Other Purposes.

It is stipulated in the declaration of the policy of that the State shall promote and improve the condition of those living in dormitories and boarding houses. Towards this end, the State shall adopt a national standard for the operation and maintenance of dormitories and boarding houses to make these facilities conducive to living and learning.

The importance of lodging houses' condition around an academic institution is not an endemic concern in Guihulngan City but a national one. A study conducted by Ruel a. Brilliantes, et al (2012) ${ }^{[2]}$ entitled, "The Living Conditions of University Students in Boarding Houses and Dormitories in Davao City, Philippines", this study determined the living conditions of university students in boarding houses and dormitories. This is anchored 
on the premise that the physical and environmental components of these residential facilities could affect the students' wholistic well-being. The researchers also came across with a similar study conducted by Dr. Dr. Alex Ylagan, et al (2013) ${ }^{[4]}$, entitled, "Compliance of Lyceum of the Philippines University Accredited Boarding Houses: Basis for a Proposed Plan of Action", this scholarly work examined the operation of boarding houses in 2008 and found the necessity to provide accredited boarding houses thru the initiative of the Office of Student Affairs.

The research entitled, "Conditions of the Nearby Boarding Houses of a State University In the Northern Philippines: A Benchmark Study conducted by Julius S. Valderama (2013) ${ }^{[3]}$, focuses on the assessment of the boarding houses near the premises of Nueva Vizcaya State University (NVSU) in northern Philippines. The boarding houses were assessed along four areas namely basic amenities, safety and security, special services and other boarders' concerns.

In international setting, the study conducted by Khumalo, Blasius Dumisani entitled, "An investigation into the educational performance of black high school students who lodge at private homes in the Nongoma circuit," focused on the private lodging house conditions and investigated the relationship between these conditions and the academic performance of black high school students.

The main goal of the study is to determine the significant relationship of the conditions of lodging houses in Guihulngan City and the academic performance of NORSU students. The physical, environmental and social conditions of the lodging houses are evaluated and were correlated to the academic performance of students to identify the relationship between the variables. The significant relationship will be the basis for policy formulation of the university through the Student Affairs Office and the policy making of the local government. This study will help policy makers on gauging the various needs of the students and this will also enrich the literature about lodging houses and academic performance.

\section{Methodology}

The method used in this study is descriptive-correlational method. This is designed to determine the relationship of two variables (X and $\mathrm{Y}$ ) whether their relationship is perfect, very high, high, marked, slight, or negligible. On the other hand, the statistical treatment of the data using Pearson Product Moment Coefficient of Correlation, this is used in identifying the relationship between the lodging house conditions and the academic performance of students. In addition, the interview of selected respondents will be accomplished to supplement and to validate the Pearson Product Moment Coefficient of Correlation statistical tool results.

This study was conducted around the premises of Negros Oriental State University, Guihulngan City Campus. Particularly the lodging houses in operation as living quarters of students enrolled in the University.

The respondents of this study will be identified through the use of random sampling in the campus of Negros Oriental State University, Guihulngan City Campus.

The data were collected through survey, interviews and documentary research. A researcher's survey guide will be developed for the purpose of gathering basic information of students residing in lodging houses. In depth interviews among selected students and operators, landlords and managers of lodging houses will be conducted. In gathering the QPA of students, the researchers will employ documentary research.

The researchers did data transcription. Data presentations (tables) and analysis will follow, together with the interpretation of the interviews. Statistical analysis will use Pearson Product Moment Coefficient of Correlation. This will identify the relationship between the lodging houses conditions and the students' academic performance.

The tools used in analyzing and in interpreting the data were the following:

Percentage: This is used to show how a part is related to a whole. It is used in presenting the profile of the respondents. Formula:

Percentage $=\frac{\text { part }}{\text { whole }} \times 100$

Mean: This is used to get the extent of performance of the respondents.

Formula:

$\overline{\mathrm{x}}=\frac{\sum x}{n}$

where $\bar{x}=$ mean/average

$\mathrm{x}=$ scores/rating

$\mathrm{n}=$ number of students

Pearson Product Moment Coefficient of Correlation: This is used in identifying the relationship between the lodging houses' conditions and the academic performance of students.

$$
\mathrm{r}=\frac{\mathrm{N}\left(\sum \mathrm{xy}\right)-\left(\sum \mathrm{x}\right)\left(\sum \mathrm{y}\right)}{\sqrt{\left.\left[\mathrm{N}\left(\sum \mathrm{x}^{2}\right)-\left(\sum \mathrm{x}\right)^{2}\right)\right]} \sqrt{\left.\left[\mathrm{N}\left(\sum \mathrm{y}^{2}\right)-\left(\sum \mathrm{y}\right)^{2}\right)\right]}}
$$

where $\mathrm{x}$ is the lodging houses' conditions $\mathrm{y}$ is the academic performance of students $\mathrm{r}$ is the coefficient of correlation To interpret the correlation value (r) obtained, the following classifications are applied:

$$
\pm 1.00 \quad \text { - perfect correlation }
$$

Between \pm 0.80 to \pm 0.99 - very high correlation

Between \pm 0.60 to \pm 0.79 - high correlation

Between \pm 0.40 to \pm 0.59 - marked/moderate correlation

Between \pm 0.20 to \pm 0.39 - low/slight correlation

Between \pm 0.01 to \pm 0.19 - negligible correlation

\section{Results}

Table 1 shows how the respondents rated their lodging houses in accordance to the following indicators: lighting and electrical facilities, ventilation and spacing, fire protection facilities, and study room.

Table 1: Physical Conditions of the Lodging House $\mathrm{N}=336$

\begin{tabular}{|cl|c|c|}
\hline \multicolumn{2}{|c|}{ Statements/Categories } & $\begin{array}{r}- \\
\text { w x }\end{array}$ & $\begin{array}{c}\text { Verbal } \\
\text { Equivalent }\end{array}$ \\
\hline 1. & Lighting and Electrical Facilities. & 3.01 & Good \\
\hline 2. & Ventilation and spacing. & 2.81 & Good \\
\hline 3. & Fire Protection Facilities. & 2.35 & Fair \\
\hline 4. & Study Room. & 2.28 & Fair \\
\hline \multicolumn{2}{|c|}{ Average } & 2.61 & Good \\
\hline
\end{tabular}


Table 1 shows the results of the Physical Condition of the Lodging House. It shows that the Lighting and Electrical Facilities, Ventilation and Spacing were GOOD and the data also indicate that the Fire Protection Facilities and Study Room were FAIR in physical conditions. Generally, it reveals that the average of the Physical Conditions of the Lodging House was GOOD. The findings above imply that the students' responses were satisfied on their Lodging Houses where they stayed although there were some facilities or even the study room of the lodging houses around NORSU Guihulngan did not meet the various needs of the occupants. However, these students came from far places of Guihulngan City specifically in the hinterlands so they were satisfied and contented of their living conditions since NORSU Guihulngan is a State University therefore mostly of the students are financially challenged.

Table 2 reflects how the respondents rated their lodging houses in accordance to the following indicators: sanitary facilities, garbage receptacles, and first aid kits.

Table 2: Environmental Conditions of the Lodging House N=336

\begin{tabular}{|l|c|c|}
\hline \multicolumn{1}{|c|}{ Statements/Categories } & W $\bar{x}$ & Verbal Equivalent \\
\hline 1. Sanitary Facilities & 2.72 & Good \\
\hline 2. Garbage Receptacles. & 2.64 & Good \\
\hline 3. First Aid & 2.18 & Fair \\
\hline \multicolumn{1}{|c|}{ Average } & 2.51 & Good \\
\hline
\end{tabular}

Table 2 above presents the results of the Environmental Conditions of the Lodging House. The table shows that the Sanitary Facilities and the Garbage Receptacles of the Lodging House were GOOD and the First Aid was FAIR. With the above findings, it reveals that it has an average of GOOD in Environmental Conditions of the Lodging House. This study indicates that some of the owner of the lodging houses fails to have First Aid in their lodging house, which is deemed very important for all the occupants for their safety and welfare.

Table 3 presents how the respondents rated the social conditions of the lodging houses using the following indicators: treatment of lodgers, imposition of house rules, relationship between lodgers and services of lodging house helpers.

Table 3: Social Conditions of the Lodging House N=336

\begin{tabular}{|l|c|c|}
\hline \multicolumn{1}{|c|}{ Statements/Categories } & $\begin{array}{r}- \\
\text { X }\end{array}$ & $\begin{array}{c}\text { Verbal } \\
\text { Equivalent }\end{array}$ \\
\hline 1. Relationship between Lodgers. & 3.21 & Good \\
\hline 2. Treatment of Lodgers. & 2.91 & Good \\
\hline 3. Imposition of House Rules. & 2.89 & Good \\
\hline 4. Services of Lodging House Helpers & 2.50 & Good \\
\hline \multicolumn{1}{|c|}{ Average } & 2.88 & Good \\
\hline
\end{tabular}

Table 3 above shows the results of the Social Conditions of the Lodging House. It shows that the overall average was GOOD. This study implies that the students were contented of the social conditions of the Lodging House where they stayed it might be because that mostly of the owners of the lodging house considered the quality of life of their occupants living on their lodging house. Furthermore, based on the results the highest average mean of 3.21 is the relationship between lodgers since the lodgers become friendlier when they stay in lodging houses than their homes because they were able to established friendships among peers. This was reflected in Maslow's Hierarchy of Needs that to be with friends or to socialize is one of the most important needs of human being.

Table 4 shows the responses of the respondents when asked about the effect of the condition of the lodging houses on their studies and their maturity.

Table 4: Maturity and Lodging House Conditions N=336

\begin{tabular}{|c|c|c|c|c|}
\hline \multirow{2}{*}{ Questions } & \multicolumn{2}{|c|}{ YES } & \multicolumn{2}{|c|}{ NO } \\
\hline & Frequency (f) & Percentage $(\%)$ & Frequency (f) & Percentage (\%) \\
\hline 1. Does your Lodging house condition contribute to your maturity? & 278 & 82.74 & 58 & 17.26 \\
\hline 2. Does your Lodging house condition affect your studies? & 218 & 64.88 & 118 & 35.12 \\
\hline
\end{tabular}

The table above presents the results on their Lodging House condition in terms of the contribution to their maturity and studies. As indicated, $82.74 \%$ of 278 students answered that the lodging house conditions will really contribute to their maturity. Furthermore, $64.88 \%$ of 218 students answered that the Lodging house conditions will affect their studies. This study shows that mostly of the respondents answered yes because it helped them become more independent and responsible. This was concluded by Estrada et al. (2008) that living in a dormitory develops the independence of the students so therefore it has a big contribution to their maturity and it also affect their studies as a whole since living in a temporary places had lesser chores in which gives them ample time to study; thus, this plays a significant contribution to their grades.

Table 5 lays out the cumulative average of students last academic year. It ranges from 1-3, with 1 being the highest and 3 being the lowest.
Table 5: Cumulative Average of the Students last Academic Year

\begin{tabular}{|c|c|c|}
\hline Ranges & Frequency (f) & Percentage (\%) \\
\hline $1.50-1.00$ & 17 & 5.06 \\
\hline $2.00-1.60$ & 249 & 74.11 \\
\hline $2.50-2.10$ & 64 & 19.05 \\
\hline $3.00-2.60$ & 6 & 1.78 \\
\hline Total & 336 & 100.00 \\
\hline
\end{tabular}

Table 5 above presents the results of the Cumulative Average of the Students last Academic Year. As indicated, $1.78 \%$ of 336 students were in the range of $2.60-3.00$. Furthermore, $74.11 \%$ belongs in the range of $2.00-1.60$ and $19.05 \%$ were in the range of $2.50-2.10$. The table also reveals that only $5.06 \%$ were classified in the range of 1.50 - 1.00. This study indicates that despite of their living conditions at home or even on their lodging houses where they stayed, still they can manage their high grades because they have accomplished their academic requirements efficiently during their stay in the lodging house and aside from that, the senior high board mates were willing to help 
the needs of the boarders in the lower years especially in academic related needs, thus, they performed better in school.

Table 6 shows the relationship between the physical conditions: lighting and electrical facilities, ventilation and spacing, fire protection and study room and the academic performance of students in the last academic year. The table also reflects the degree of relationship between the two variables.

Table 6: Academic Performance and the Physical Conditions of the Lodging House.

\begin{tabular}{|c|c|c|c|}
\hline \multicolumn{2}{|c|}{ Statement } & $\begin{array}{c}\text { Computed } \\
\mathbf{r}_{\text {s }}\end{array}$ & $\begin{array}{c}\text { Degree of } \\
\text { Relationship }\end{array}$ \\
\hline 1 & $\begin{array}{c}\text { Lighting and } \\
\text { Electrical Facilities }\end{array}$ & 0.707 & High relationship \\
\hline 2 & $\begin{array}{c}\text { Ventilation and } \\
\text { Spacing }\end{array}$ & 0.711 & High relationship \\
\hline 3 & $\begin{array}{c}\text { Fire Protection } \\
\text { Facilities }\end{array}$ & 0.649 & $\begin{array}{c}\text { Marked/Moderate } \\
\text { relationship }\end{array}$ \\
\hline 4 & Study Room & 0.618 & $\begin{array}{c}\text { Marked/Moderate } \\
\text { relationship }\end{array}$ \\
\hline
\end{tabular}

Table 6 indicates that there is a "high relationship" between the academic performance of the students last academic year and the following physical conditions of the lodging house: lighting and electrical facilities; ventilation and spacing. Meanwhile a "marked/moderate relationship" existed between the academic performance of the students and the physical conditions of the lodging house on: fire protection facilities and study room. This study implies that the relationship of students' academic performance and the physical conditions in terms of lighting and electrical facilities, ventilation and spacing has a high relationship in terms of their grades though their responses were only good in physical conditions on their lodging houses, however, the students were contented and satisfied because they got a high grades during their stay in a lodging house.

This study was concurred by the study of Brilliantes (2012)

${ }^{[2]}$ that the academic performance of students has improved during their stay in the boarding houses or dormitory because they can accomplish academic requirements efficiently during their stay in the boarding house. Meanwhile, the fire protection facilities and study room has a "marked/moderate relationship" in terms of their academic performance. This simply means that the students were not totally affected with their academic performance on the conditions of their lodging house because the respondents are coming from the hinter land so therefore they are contented of their stay and they can study their lessons because no household chores can interrupt when they are studying and board mates also can help them in terms of academic related needs. This study was also concurred by Brilliantes (2012) ${ }^{[2]}$ that if a student resides with board mates or roommates who really value education and who extend time in studying, he will eventually become like them, thus, academic success is inevitable. This was because students are more matured when living in a boarding house because they are independent and responsible in terms of decisions making.

Table 7 presents the relationship between the environmental conditions of the lodging houses: sanitary facilities, garbage receptacles and first aid and the academic performance of students in the last academic year. It also shows the degree of relationship between the two variables.
Table 7: Academic Performance and the Environmental Conditions of the Lodging House.

\begin{tabular}{|l|c|c|}
\hline \multicolumn{1}{|c|}{ Statement } & Computed $\mathbf{r}_{\mathbf{s}}$ & $\begin{array}{c}\text { Degree of } \\
\text { Relationship }\end{array}$ \\
\hline 1.Sanitary Facilities & 0.650 & Moderate relationship \\
\hline 2. Garbage Receptacles & 0.658 & Moderate relationship \\
\hline 3. First Aid & 0.612 & Moderate relationship \\
\hline
\end{tabular}

Table 7 indicates that there is a "moderate relationship" between the academic performance of the students last academic year and the following environmental conditions of the lodging house: sanitary facilities; garbage receptacles; and first aid. This implies that the students were not really affected with the environmental conditions of the lodging house where they stayed in terms of their academic performance because their responses were all good in sanitary facilities and garbage receptacles and fair in first aid because what they care of was their academic performance so they do not care on their environmental conditions and aside from that mostly of the students were from the mountain area, so they were satisfied in their environmental conditions as practiced in their respective places. They do not know that the environmental conditions were very important also for all the occupants for their security and safety in terms of health services.

Table 8 shows the relationship between the social conditions of the lodging houses: treatment of lodgers, imposition of house rules, relationship between lodgers and services of lodging house helpers and the academic performance of students in the last academic year.

Table 8: Academic Performance and the Social Conditions of the Lodging House.

\begin{tabular}{|c|c|c|c|}
\hline \multicolumn{2}{|c|}{ Statement } & $\begin{array}{c}\text { Computed } \\
\text { rs }\end{array}$ & $\begin{array}{c}\text { Degree of } \\
\text { Relationship }\end{array}$ \\
\hline 1 & Treatment of Lodgers & 0.711 & High relationship \\
\hline 2 & $\begin{array}{c}\text { Imposition of House } \\
\text { Rules }\end{array}$ & 0.741 & High relationship \\
\hline 3 & $\begin{array}{c}\text { Relationship between } \\
\text { Lodgers }\end{array}$ & 0.598 & $\begin{array}{c}\text { Marked/Moderate } \\
\text { relationship }\end{array}$ \\
\hline 4 & $\begin{array}{c}\text { Services of Lodging } \\
\text { House Helpers }\end{array}$ & 0.684 & $\begin{array}{c}\text { Marked/Moderate } \\
\text { relationship }\end{array}$ \\
\hline
\end{tabular}

Table 8 indicates that there is a "high relationship" between the academic performance of the students last academic year and the following social conditions of the lodging house: treatment of lodgers and imposition of house rules. Meanwhile a "marked/moderate relationship" existed between the academic performance of the students and the social conditions of the lodging house on: relationship between lodgers and the services of lodging house helpers.

This shows that the relationship between the academic performance and the social conditions of the lodging house in terms of treatment of lodgers and imposition of house rules has a high relationship. The operator of the lodging house has a big role for the academic performance of the students because they are the one who facilitated the boarders to be socialized because they are away from their family so it might create loneliness or got sick while staying the boarding house. Thus, the operator must consider creating social activities to their occupants to overcome the loneliness and students can focus on their studies because when you get bored the students might be depressed.

This study was concurred by Estrada (et al., 2008) that social activities in boarding houses/dormitories create 
essentialities in the lives of the students. Since, being away of from one's family creates the feeling of homesickness and loneliness; experts agree that one of the best ways to cope with these is to get involved in activities. In addition, the relationship between the lodgers and the services of lodging house helpers has marked/moderate relationship. This indicates that it also affects their academic performance in socializing other occupants of the lodging house because if you have a good relationship with the other occupants then you can focus on your study as well.

According to the study of Brilliantes (2012) ${ }^{[2]}$ that if the students were able to establish friendships among other occupants then it will creates sense of belongingness. It was also reflected by the study of Maslow's Hierarchy of Needs that to be with friends or to socialize is one of the most important needs of a human being. In addition, students living in a lodging house had a big chance to participate in all extra-curricular activities conducted by the school, thus, they performed better in school. This was reflected by the study of De Larrosa (2000) that living away from home increases leadership and interpersonal skills and cultural awareness.

\section{Discussion \\ Physical Conditions of the Lodging Houses}

The results show that the lighting and electrical facilities have the highest rating among all the physical condition of lodging houses is the lighting and electrical facilities with a mean of 3.01 with the verbal equivalent of good. It is followed by ventilation and spacing with a mean of 2.81 with a verbal equivalent of good. Moreover, the fire protection facilities and study room has a verbal equivalent of fair and has mean of 2.35 and 2.28 respectively. Overall, the physical condition of lodging houses has and average of 2.61 with a verbal equivalent of good.

\section{Environmental Conditions of the Lodging Houses}

The result expresses that topping the table among the environmental conditions is the sanitary facilities with a mean of 2.72 and a verbal equivalent of good, and followed closely by the presence of garbage receptacles with a mean of 2.64 and a verbal equivalent of good. The first aid is the least in rank with a mean of 2.18 and a verbal equivalent of fair. The overall average of the environmental conditions of lodging houses is 2.51 , which has a verbal equivalent of good.

\section{Social Conditions of the Lodging Houses}

The results lay out the social conditions of the lodging houses that the relationship between the lodgers topped the ranking with a mean of 3.21 and a verbal equivalent of good. Followed behind by treatment od lodgers, imposition of house rules and services of lodging house helpers with a mean of $2.91,2.89$, and 2.50 respectively with a verbal equivalent of good. The average mean of the social condition of lodging houses is 2.88 with a verbal equivalent of good.

\section{Academic Performance of students staying in Lodging Houses}

The results show that 5. 06 percent of the respondents or a frequency of 17 had a cumulative average that ranges from 1.50 to 1 . 00 . 74.11 percent of the respondents or a frequency of 249 had a cumulative average that ranges from
2.00 to 1.60 .19 .05 percent of the respondents or a frequency of 64 had a cumulative average that ranges from 2.50 to 2.10. Lastly, 1.78 percent of the respondents or a frequency of 6 had a cumulative average that ranges from 3.00 to 2.60. A total of 336 respondents where asked to answer the questionnaires.

\section{Academic Performance and Lodging House Conditions} Academic Performance and the Physical Conditions of the Lodging House: The results show that the computed rvalue of the lighting and facilities against the cumulative average of students is 0.707 with the degree of relationship is high relationship. The computed r-value of the ventilation and spacing against the cumulative average of students is 0.711 with the degree of relationship is high relationship. The computed r-value of the fire protection facilities against the cumulative average of students is 0.649 with the degree of relationship is moderate relationship. And the computed r-value of the study room against the cumulative average of students is 0.618 with the degree of relationship is moderate relationship.

Academic Performance and the Environmental Conditions of the Lodging House: The result express the computed r-value of sanitary facilities against the cumulative average of students is 0.650 with the degree of relationship is moderate relationship. The computed $r$-value of garbage and receptacles against the cumulative average of students is 0.658 with the degree of relationship is moderate relationship. Lastly, the computed r-value of the first aid against cumulative average is 0.612 with the degree of relationship is moderate relationship.

Academic Performance and the Social Conditions of the Lodging House: The result presents the computed r-value of treatment of ledgers against the cumulative average of the students is 0.711 with the degree of relationship is high relationship. The computed r-value of the imposition of house rules against the cumulative average of students is 0.741 with the degree of relationship is high relationship. The computed r-value of the relationship between lodgers against the cumulative relationship of students is 0.598 with the degree of relationship is moderate relationship. And the computed r-value of the services of lodging house helpers against the cumulative average of students is 0.684 with the degree of relationship is moderate relationship.

\section{Conclusion}

Based on the findings presented above, the following conclusions are drawn:

The physical condition of the lodging houses has an average mean of 2.6, the environmental condition of the lodging houses has an average of 2.51 and the social conditions of the lodging houses has an average mean of 2.88 , which is good in its verbal equivalent respectively. This means that students who are living in lodging houses are comfortable of their quarters, regardless of size or the presence of available facilities and the social atmosphere. This present a persistent problem regarding the conformity or adherence to lodging house standards because owners will not be encourage to improve the physical, environmental and social conditions of the lodging houses, since the lodgers are satisfied with or thought that their living quarters are sufficient and already are as sound as the standards. 
The data showed that majority of the students living in lodging houses has a cumulative average that ranges from 2.00 to 1.60 and a frequency of 249 . This indicated that mostly of the respondents staying in lodging houses are academically excellent. The factors that contributed to this performance are self-determination and the help of senior students living in the same lodging house. The students' stay in lodging houses contributed to their maturity (see table 4), making them adept and reactive to the academic demands in the university.

Furthermore the data showed that there is a significant relationship between the academic performances and the condition of the lodging houses, particularly the physical conditions, environmental conditions and social conditions. It is therefore apparent that the good living conditions contributed to the academic performance of students in the university. Though the conditions are below the standards students of the university, they still excel in their academics. This is in consonance to the study of De Larrosa (2000), which stated that living away from home increases leadership and interpersonal skills and cultural awareness. It is therefore important for the students to be staying in a sound-lodging house to have a holistic growth and development, both cognitively and socially.

\section{References}

1. Chickering AW, Reisser L. Education and Identity (2nd edition). San Francisco: Jossey-Bass, 1993.

2. Ruel A, Brilliantes, et al entitled, The Living Conditions of University Students in Boarding Houses and Dormitories in Davao City, Philippines, 2012.

3. Julius S Valderama. Conditions of the Nearby Boarding Houses of a State University in the Northern Philippines: A Benchmark Study, 2013.

4. Dr. Alex Ylagan, et al. Compliance of Lyceum of the Philippines University Accredited Boarding Houses: Basis for a Proposed Plan of Action, 2013.

5. Maria Cona Futalan, et al. Correlation between the High School English Grades of Freshmen Students and Their Performance in the College Entrance Placement Test in English, 2011.

6. Sen. Manny Villar. Senate Bill no. 1113, An Act Establishing A Comprehensive And Integrated National Policy And Program Guidelines For The Operation And Maintenance of Dormitories and Boarding-Houses, Providing Penalties Therefor, and For Other Purposes, 2012.

7. http://www.ucalgary.ca/ses/studentdevelopmenttheory

8. http://thesocialworkexam.com/maslows-theory-ofbasic-needs-learning

9. http://iamure.com/publication/index.php/ijbm/article/vi ew/477

10. http://uzspace.uzulu.ac.za/handle/10530/677. 